\title{
Cranial morphology of European passerine bird families (Aves, Passeriformes)
}

\section{Péter UJHELYI}

Received: June 24, 2016 - Accepted: November 30, 2016

Péter Ujhelyi 2016. Cranial morphology of European passerine bird families (Aves, Passeriformes). - Ornis Hungarica 24(2): 54-77.

Abstract The subject of this study focuses on the cranial morphology of 24 native European passerine bird families. In addition to the discussion of taxonomical questions regarding to the examination of beak, orbit, cranium and mandible, the author aims to provide guidance to the determination of raptors' prey remains. Most of the studied bird families are well-distinguishable using the knowledge on the mentioned osteological traits except some less-specialised families.

Keywords: taxonomy, determination, cranial morphology, songbirds

Összefoglalás A dolgozat az Európában honos 24 énekesmadár-család koponyamorfológiai jellemzésével foglalkozik. A csőr, a szemgödör, az agykoponya és az állkapocs vizsgálatával a szerzö egyes taxonómiai kérdések megvitatása mellett a ragadozómadarak zsákmánymaradványainak meghatározásához kíván segítséget nyújtani. A vizsgált madárcsaládok többsége a felsorolt csonttani bélyegek ismeretében jól elkülöníthetö, csupán néhány kevéssé specializált család meghatározása jelenthet gondot.

Kulcsszavak: Aves, Passeriformes, koponyamorfológia, határozás, taxonómia

MME/BirdLife Hungary, 1121 Budapest, Költö utca 21., Hungary, e-mail: ujhelyi.peter@mme.hu

\section{Introduction}

Studying of avian osteo-morphology has a tradition dated back to the middle of the $19^{\text {th }}$ century. Initially, the skeletal system was examined particularly in systematic perspectives: the structure of the palate (Huxley 1867, Hofer 1945, Witmer \& Martin 1987, Zusi 1993), the sternum and humerus (Fürbringer 1888), the cranium, sternum, shoulder, pelvis and hindlimb (Suschkin 1905), number of the vertebra (Boas 1929, Zweers et al. 1987), and the morphology of carpometacarpus (Steiner 1922, Lambrecht 1933, Hinchliffe 1985) was considered in distinguishing the larger bird orders. In the past century, mainly palaeontologist used comparative osteo-morphological methods and studied less vulnerable skeletal compartments from excavations. Although, the examination of postcranial parts of the skeleton is dominant in paleontological researches, in some cases, the determination of cranial remains may also be necessary (Jánossy 1992). Whereas, fossils can confidently be classified among recent species, only with deep knowledge on bones (Lambrecht 1933), thus classical morphological researches - simultaneously with the emergence of molecular taxonomy - should be preserve their roles in systematics (Judin 1978). Several detailed osteological collections of different bird groups, which could also facilitate paleontological studies, have been made to date: Podicipediformes (Bochenski 1994), Ardeidae (Boev 
1988), Anseriformes (Bacher 1964, Woelfle 1967), Galliformes (Ebersdobler 1968, Kraft 1972), Charadriiformes (Barbosa 1991), Columbidae (Fick 1974), Falconiformes (Otto 1981, Schmidt-Burger 1982, Solti 1980, 1981a, 1981b, 1994), Strigiformes (Winde 1970, Langer 1980), Picidae (Kessler 2016).

Despite passerines constitute most probably the prey of owls (März 1987), finches (Finckenstein 1937, Moreno 1985, Ujhelyi 1992) and corvids (Tomek \& Bochenski 2000) are the most intensively studied groups within this order. The only detailed studies including more bird families are Jánossy's (1983) guide for humerus and the works of Moreno (1985, 1986, 1987), and Cuisin (1989) about the Spanish and French fauna. Numerous parts of the skeleton are also presented in Kessler (2015).

I assembled the craniomorphological characterization of 24 native European passerine families in this study. Besides the premaxilla and the cranium, I paid special attention to the morphology of mandible, because bone remains can be identified significantly easier with the knowledge on the structure of the pars caudalis mandibulae. Other authors did not attribute sufficient importance to it, however the complete pars caudalis mandibulae can often be found among food remains. Furthermore, my work contains the anatomy of the vomer since previous researches entirely omitted this. This study is based on the comparative osteological collection of the Hungarian Natural History Museum. Some specimens of a few groups were studied in the Paleontological Institute of the Russian Academy of Science (Moscow) and in the Museum of Natural History, Vienna (Naturhistorisches Museum, Vienna). I asked G. Csorba from the zoological collection of the Berlin's Museum of Natural History (Museum für Naturkunde, Berlin) to carry out some comparative examinations, particularly for this study. I would like to emphasize with the list of genera of each family that I mainly considered the European members of these families in the compilation of cranial morphology for this study. The original illustrations completed this text were also made in the above-mentioned collections. The delimitation of each bird families follows Voous (1977), however their order differs, because here I present sequentially the osteologically more related groups. Although, the linear listing could never perfectly reflect the complex system of songbirds, but it is remarkable that the osteological characteristics could be comparable with the biochemistry based systematics of Sibley and Ahlquist (1990) in many instances. Newertheless, the nomenclature of this study can partially be followed using the work of Baumel et al. (1979), I explain the terms on explanatory figures.

\section{Corvidae}

(Perisoreus Bonaparte, 1831; Garrulus Brisson, 1760; Cyanopica Bonaparte, 1850; Pica Brisson, 1760; Corvus Linnaeus, 1758; Nucifraga Brisson, 1760; Pyrrhocorax Tunstall, 1771)

Corvids are large songbirds which can already be distinguished by body size from other members of their order. Their upper beak is robust, the length of the pars praenarialis is often larger than the diameter of the nostril. The nostril is completely open in most of the species, but for example in Pyrrhocorax pyrrhocorax it is splitted by a horizontal bone plate. In some specimens of Corvus corax a well-developed septum nasi is located in the nasal 
cavity, however this bone membrane is vestigial or absent in most of the species. In plan view the brachium processi maxillopalatini is visible through the nostril and the foramen basale forms its base. The corpus processi maxillopalatini is also well-developed and it is partialy hollow in some genera. The edges of the vomer are dorsally retracted on both sides, the processus corniculatus vomeris is well-developed. The incisura interpalatina is usually narrow and there is a bone crest on the ventral surface of the lamella caudolateralis. The foramen orbitonasale is a long gap in most of the cases but it can be devided by bone plates into more parts. The septum interorbitale is well-developed and thick. The fenestra olfactoria can be found in numerous genera (Perisoreus, Garrulus, Pyrrhocorax, Pica, Cyanopica), but this aperture is bony in Nucifraga and Corvus species. The rostrum sphenoidale is thickened in most of the species. The processus orbitosphenoidalis lateralis is particularly developed in Nucifraga caryocatactes. The processus postorbitalis and the processus zygomaticus ossis squamosi are moderately developed. The symphysis mandibulae is weak in the case of Perisoreus infaustus but in the species of other genera (Nucifraga, Pyrrhocorax) it is remarkably long. The foramina postsymphysialia are opened on the caudal edge of the symphysis, except for the Nucifraga genus, where these apertures are located on the ventral surface of the symphysis. Behind the foramen laterale the impressio mandibularis is moderately pronounced and the oval fenestra mandibulae is relatively small. On the ventral surface of the pars caudalis mandibulae between the peaks of the processus externus and the processus internus a $\mathrm{V}$-shaped bone ridge streches.

\section{Oriolidae}

(Oriolus Linnaeus, 1766)

The upper beak is massive and the length of the bony palate approaches the half of the beak. The pars praenarialis is larger than the diameter of the nostril. The remnant of the septum nasi is located on the rostral end of the naval cavity. The wide brachium processi maxillopalatini and the foramen basale near its base are visible in plan view. At the end of its extension the lengtheneed corpus is hardly separated. The simply structured vomer is little pneumatized and the processus corniculatus vomeris is short. The incisura interpalatina ends at the base of the processus spiniformis. The remarkably spacious, single (not split) foramen orbitonasale opens close to the axis of the skull. The fenestra olfactoria is strongly lengthened in rostral direction, the fenestra septi interorbitalis is always located. The processus postorbitalis and the processus zygomaticus ossis squamosi is moderately developed, where extensions could not be found on the caudal bony wall near the eye socket. The $f o-$ ramina venae occipitalis externae opens far from each other and behind the foramen magnum. The slim mandible is slightly hooked in lateral view and there is no significant nook (impressio mandibularis) on the lateral surface of the mandible. The foramen laterale is also absent. The symphysis is well-developed, but the fenestra mandibulae is small. The bone ridge is vestigial on the ventral surface of the pars caudalis mandibulae. The fossa caudalis mandibulae is basically absent between the peak of the processus externus and the processus internus. 


\section{Laniidae}

(Lanius Linnaeus, 1758)

The upper beak of Lanius species is relatively short and strength. The septum nasi is always located between the nostrils. The foramen basale opens at the base of the wide brachium processi maxillopalatini which is visible in plan view. The corpus processi maxillopalati$n i$ is barely separated from the brachium in their morphology. The structure of the pneumatized vomer is complex, the paired processus corniculatus vomeris is dorsally strongly curved. The incisura interpalatina is relatively wide, the lamella caudolateralis forms a long extension. In Lanius species the rostral part of the pterygoideum fusions to the palatinum differently to the majority of songbirds. The foramen orbitonasale is split: the foramen orbitonasale laterale is larger than the $f$. o. mediale. The fenestra septi interorbitalis is never completely bony. The processus postorbitalis is vestigial and the processus zygomaticus ossis squamosi is moderately developed. The foramina venae occipitalis externae open close to each other and these apertures are connected to the edge of the foramen magnum via the paired sulcus occipitalis. The symphysis mandibulae is moderately thick, the impressio mandibularis is varied by species. The foramen laterale is absent. The wide-based tuberculum pseudotemporale is moderately developed. A sharp bone ridges is located on the ventral surface of the processus internus. The fossa caudalis mandibulae is barely expressed.

\section{Hirundinidae}

(Hirundo Linnaeus, 1758; Delichon Horsfield et Moore, 1854; Riparia Forster, 1817; Ptyonoprogne Reichenbach, 1850)

The typically prolate beak of swallows and martins makes the members of this family to easily recognizable. The brachium processi maxillopalatini is not visible over the nostril, but it is located behind the processus postnarialis. The foramen basale exists. The vomer is flat, the contour of the processus corniculatus is angular. The basically wide incisura interpalatina ends at the peak of the processus spiniformis. The pars interorbitalis is narrow, the septum interorbitale is thin. The foramen orbitonasale is split: the $f$. o. laterale is smaller then the $f$. o. mediale. The fenestra olfactoria and the fenestra septi interorbitalis are spacious. The processus postorbitalis and the processus zygomaticus ossis squamosi weakly developed. A paired groove (sulcus occipitalis) extends between the foramen magnum and the foramina venae occipitalis externae. The symphysis mandibulae is weak, the foramina postsymphysialia open far from each other on its dorsal surface. The mandible branches are widely expanded. The angulus mandibulae is typical of the mandible with a peak in its middle. The processus internus is not visible in lateral view and bone ridge is never located on its ventral surface. The fossa caudalis mandibulae is deeply curved.

Comment: The swallows form a very special group of songbirds. Their anatomical specializations regarding to their lifestyle make it difficult to identify which families are closely related to them. Whereas the Corvidae-Oriolidae-Laniidae triplet is farther related to all other passerines than the swallows, thus I have listed them here right after the Laniidae. 
It needs to be considered in the practice of the determination of families that the skull of the swallows remind to the skull of the swifts (Apodiformes: Apodidae), however these two groups differ in many morphological traits. The nook (impressio supraorbitalis) behind the pars interorbitalis, and the lateral position of the foramina venae occipitalis externae separate swifts from any other songbirds.

\section{Bombycillidae}

(Bombycilla Vieillot, 1808)

The upper beak with a significant widening at its base is relatively short. The bony palate is also shortened. The nostril is spacious and the septum nasi is always absent. The corpus processi maxillopalatini is short, wide and partially pneumatized. The vomer is flat and the contour of the processus corniculatus is angular. The wide incisura interpalatina is protractedly wedged forward. The orbital surface of the weakly pneumatized ala mesethmoidei is concave. The split-like foramen orbitonasale is single (not split). The fenestra septi interorbitalis is bony and absent in adults, whilst the fenestra olfactoria is remarkably spacious. The processus postorbitalis is almost melded into the cranium and the processus zygomaticus ossis squamosi is also vestigial. The ala tympanica hardly covers the cavum tympani in lateral view. The foramina venae occipitalis externae open at the end of one-one paired groove (sulcus occipitalis) behind the foramen magnum. The symphysis mandibulae is short, the mandible branches are widely expanded. The impressio mandibularis is always located and the foramen laterale opens in front of it. The ventral surface of the pars caudalis mandibulae is smooth, the fossa caudalis mandibulae is moderately notched. The axis of the lengthened processus internus mandibulae is approximately right angles to the mandible branch.

\section{Sturnidae}

(Sturnus Linnaeus, 1758; Pastor Temminck, 1815)

The upper beak is slim and pointed. The nostrils are spacious. The septum nasi is always absent. The brachium processi maxillopalatini is visible through the nostrils in plan view and the foramen basale is absent at the bottom of it. The strongly lengthened corpus processi maxillopalatini is partially pneumatized. A weak bone ridge is located at the midline of the vomer, the processus corniculatus vomeris is vestigial. The incisura interpalatina ends at the middle of the lengthened collum vomeris. The foramen orbitonasale is split: the larger f. o. mediale is in the interior eye cavity while the small $f$. o. laterale opens at the edge of the eye cavity. The fenestra septi interorbitalis can be found in both young and adult birds. The processus postorbitalis is barely appreciable, the processus zygomaticus ossis squamo$s i$ is also vestigial. A typical hump is located on the ventral surface of the rostrum sphenoidale. The foramina venae occipitalis externae open directly at the edge of the foramen magnum. In some species (Sturnus spp.), a sharp bone ridge (crista nuchae) extends at the edged of the regio occipitalis. A typical characteristic of the mandible is the mid-peaked angulus mandibulae in lateral view. The foramen laterale is absent near the impressio mandibularis. The canalis mandibulae opens just before the fenestra mandibulae at the lateral surface of 
the mandible. The two European starling genera (Sturnus, Pastor) significantly differ in the structure of the pars caudalis mandibulae: the processus externus is already well-developed in the young of the Sturnus species, however in Pastor roseus this has standard size. A more or less developed hump is located at the rostral edge of the processus internus.

Comment: The differences in the morphology of the pars caudalis mandibulae absolutely justify the split of Sturnus and Pastor genera.

\section{Cinclidae}

(Cinclus Borkhausen, 1797)

The upper beak is slim and sharp and at its ridge, a weak concavity can be found before the processus dorsonarialis. The septum nasi is absent in the spacious and lengthened naval cavity. The brachium processi maxillopalatini is invisible in plan view. A sharp bone ridge extends at the midline of the lengthened vomer, which continues in a long bone mandrel at the front of the vomer. The lamella caudolateralis is significantly shortened. The pars interorbitalis is relatively narrow. The ala mesethmoidei is strongly pneumatized and it is markedly protuberant on its orbital surface. The foramen orbitonasale is split, the f. o. laterale opens at the edge of the eye cavity and it is also visible in plan view. The fenestra olfactoria and the fenestra septi interorbitalis are both spacious. The processus postorbitalis is small and rounded, the processus zygomaticus ossis squamosi is vestigial. The fenestra mandibulae is a relatively small aperture on the rearer part of the mandible and the canalis mandibulae opens just before this at the lateral surface of the mandible. A sharp bone ridge is located on the ventral surface of the pars caudalis mandibulae which is split into two branches and extends to the rear extension of the mandible (processus externus et processus internus).

\section{Troglodytidae}

(Troglodytes Vieillot, 1807)

The upper beak is slim, the diameter of the nostrils and the length of the pars praenarialis are equal. The septum nasi is absent in the naval cavity. The thin and hooked brachium processi maxillopalatini is invisible through the nostril in plan view. At the base of this extension, the foramen basale is absent and the corpus processi maxillopalatini is not pneumatized. The vomer is flat and the processus corniculatus vomeris is small. The incisura interpalatina is wide and the processus spiniformis is lengthened. The foramen orbitonasale is single (not split). The fenestra olfactoria and the fenestra septi interorbitalis are both spacious. The processus zygomaticus ossis squamosi is vestigial and a relatively sharp bone ridge extends behind it, between the small processus postorbitalis and the tympanic cavity (cavum tympani). The mandible is slim and slightly curved in lateral view. The impressio mandibularis is absent on its lateral surface. The lateral surface of the processus externus mandibulae is convex. 


\section{Certhiidae}

(Certhia Linnaeus, 1758)

The upper beak is thin and slim and strongly curved in lateral view. The septum nasi is absent in the naval cavity. The foramen basale is absent, the hooked brachium processi maxillopalatini is behind the processus postnarialis in plan view. The corpus processi maxillopalatini is pneumatized. A tiny bone ridge is visible at the midline of the vomer, the processus corniculatus vomeris is vestigial. The wide incisura interpalatina is wedged in front of the short processus spiniformis. The foramen orbitonasale is single (not split). The septum interorbitale is relatively well-developed, the fenestra olfactoria and the fenestra septi interorbitalis is smaller than on the skull of the Troglodytidae and Regulidae families. The processus postorbitalis and the prosessus zygomaticus ossis squamosi are both vestigial. The moderately sharp crista nuchae separates well the occiput area (regio occipitalis). The mandible is strongly curved in lateral view. The foramina postsymphysialia open at the end of the symphysis in a ventral groove. The little deviated, slim processus externus mandibulae is typical for the pars caudalis mandibulae which lateral surface is slightly concave.

\section{Tichodromadidae}

(Tichodroma Illiger, 1811)

The upper beak is long and thin, the length of the pars praenarialis and the nostril are equal. The septum nasi is absent in the naval cavity. The brachium processi maxillopalatini is invisible through the nostril in plan view. The lamella caudolateralis is short and rounded. The foramen orbitonasale is split. The septum interorbitalis is strongly perforated, the fenestra olfactoria is larger than the fenestra septi interorbitalis. The mandible is thin and curved and the symphysis mandibulae is well-developed. The fenestra mandibulae is vestigial and almost completely bony.

\section{Sittidae}

(Sitta Linnaeus, 1758)

The upper beak is long and slim, the diameter of the spacious nostril is slightly smaller than the length of the pars praenarialis. The septum nasi is absent in the naval cavity. The brachium processi maxillopalatini is invisible through the nostril in plan view. The very wide incisura interpalatina extends in front of the processus spiniformis. The foramen orbitonasale is a single (not split) aperture. The septum interorbitalis is highly developed, the fenestra septi interorbitalis is completely bony and the fenestra olfactoria is also significantly narrowed. The processus zygomaticus ossis squamosi and the processus postorbitalis are both developed. The hardly curved mandible is powerful and chisel-like. The foramina postsymphysialia open close to each other at the caudal edge of the symphysis. The foramen laterale is located in front of the impressio mandibularis. The processus coronoideus forms a sharp bone ridge above the relatively narrow fenestra mandibulae. Typical characteristics of the lateral edge of the pars caudalis mandibulae are the twin bone peaks and the rounded processus externus. 


\section{Paridae (s. str.)}

(Parus Linnaeus, 1758)

The upper beak is short and massive, the diameter of the oval nostril is much smaller than the length of the regio praenasalis. The remnant of the bony bracing membrane (septum nasi) is always located at the caudal part of the naval cavity. The processus dorsonarialis is remarkably wide, the upper beak and the forehead is sharply separated by the sulcus frontonasalis rectus behind it. The brachium processi maxillopalatini is invisible through the nostril in plan view. The corpus processi maxillopalatini is short and partially pneumatized. The shape of the lengthened vomer differs by species. The incisura interpalatina is more wedged in front of the vestigial processus spiniformis often forwards to the collum vomeris. The lamella caudolateralis is barely developed, however the lamella caudomedialis is significantly wide. The foramen orbitonasale is split. The septum interorbitale is robust, the fenestra olfactoria is relatively narrow and the fenestra septi interorbitalis is ofthen completely bony. The processus postorbitalis is absent and the processus zygomaticus ossis squamosi is weakly developed. The mandible is relatively short and the symphysis is well-devleoped. The foramina postsymphysialia open close to each other in the groove on the dorsal surface of the symphysis. The foramen laterale is always located at the base of the sharply separated impressio mandibularis. The fenestra mandibulae is large and remarkably spacious in some species (e.g. Parus caeruleus). The ventral surface of the pars caudalis mandibulae is smooth and the processus externus is moderately developed and its contour is angular.

\section{Remizidae}

(Remiz Jarocki, 1819)

The upper beak is relatively short and triangular, the diameter of the nostril is much smaller than the length of the pars praenarialis. The septum nasi is well-developed in the naval cavity. The processus dorsonarialis is remarkably wide as in Parus species. The slightly curved vomer has multiple peaks and behind it, the collum vomeris significantly narrows. The incisura interpalatina is bony on a significant part, a slight notch can only be found on a short caudal part of the palatinum. The processus spiniformis is vestigial, but the lamella caudolateralis is spikwise lengthened. The septum interorbitale is relatively perforated: the fenestra olfactoria and the fenestra septi interorbitalis are both well-developed and behind the single (not split) foramen orbitonasale, an extra aperture breaks through the bone membrane. The processus postorbitalis is absent and the processus zygomaticus ossis squamosi is vestigial. The sharp edge of the margo postorbitalis merges into the cranium above the processus zygomaticus.The structure of the curved mandible is special and can be distinguished from any other songbirds: the lengthened processus externus is much longer than the processus internus. The latter extension contains a sharp bone peak at its rostral edge. The relatively narrow fenestra mandibulae is located on approximately equal distance between the caudal end of the symphysis and the peak of the processus externus. The position of the foramina postsymphysialia and the foramen laterale does not differ from the drescition in the Paridae family. 
Comment: The Remizidae family is highly separated in the structure of the pars caudalis mandibulae from the Paridae and any other European passerine families.

\section{Aegithalidae}

(Aegithalos Hermann, 1804)

The typically shaped upper beak is short, the diameter of the spacious nostril sometimes exceeds the length of the pars praenarialis. Opposite to the Paridae and the Remizidae families, the septum nasi still could not be found in vestigial form too, the processus dorsonarialis is even narrower. The thin brachium processi maxillopalatini is invisible through the nostril in plan view. The two well-developed processus corniculatus vomeris at the beginning of the vomer contact to each other along the symmetry axis of the skull. The incisura interpalatina is wide and long, the lamella caudolateralis is short and rounded. The foramen orbitonasale is single (not split). The septum interorbitale is strongly perforated, the fenestra olfactoria and the fenestra septi interorbitalis are both well-developed. The processus postorbitalis is absent. The peak of the moderately developed processus zygomaticus ossis squamosi is widely rounded and the margo postorbitalis arches uninterruptedly to this peak. The foramina postsymphysialia open at the caudal edge of the moderately developed symphysis. The fenestra mandibulae is moderately spacious. The morphology of the pars caudalis mandibulae is mainly equal to Parus species, however the processus externus is slightly shifted outwards.

\section{Paradoxornithidae}

(Panurus Koch, 1816)

The upper beak is slim, the length of the pars praenarialis and the diameter of the nostril are equal. The septum nasi is always absent in the naval cavity and the processus dorsonarialis is relatively narrow. The brachium processi maxillopalatini is invisible in plan view and the foramen basale is absent at the base of this extension. The corpus processi maxillopalatini is lengthened and pneumatized. The vomer has multiple peaks. The wide incisura interpalatina extends in front of the short processus spiniformis. The foramen orbitonasale is single (not split). The fenestra olfactoria and the fenestra septi interorbitalis are both welldeveloped. The tiny processus postorbitalis is melted in full length to the dorsal edge of the processus zygomaticus ossis squamosi in a specific way, but a negligible gap can be found between these two extensions in some young specimens. The mandible is slightly curved and the symphysis is weakly developed. The foramen laterale is located in front of the impressio mandibularis. A weak bone ridge extends at the ventral surface of the pars caudalis mandibulae and the processus externus is vestigial and widely rounded.

Comment: The Panurus biarmicus can be separated from any other European songbirds based on the rounded shape of the processus externus mandibulae. 


\section{Regulidae}

(Regulus Cuvier, 1800)

The upper beak is slim and sharp, the processus postnarialis is particularly thin. A specific trait of Regulus species is the vestigial septum nasi in the caudal part of the nasal cavity. The brachium processi maxillopalatini is visible through the nostril in plan view too, at its end the corpus is relatively wide, lengthened and not pneumatized. The midline of the vomer is little peaked and the processus corniculatus vomeris is well-developed. The wide incisura interpalatina is wedged to the peak of the lengthened processus spiniformis. The foramen orbitonasale is single (not split). The fenestra olfactoria and the fenestra septi interorbitalis are both remarkably spacious. The processus postorbitalis is vestigial and the processus zygomaticus ossis squamosi is moderately developed. The mandible is lengthened and thin and the fenestra mandibulae is relatively spacious. The protuberantia caudolateralis is ridge-like developed at the lateral surface of the pars caudalis mandibulae, a tiny aperture (foramen pneumaticum) can be found behind it. The peak of the processus internus is remarkably sharp.

Comment: Based on their measurement the Regulus species are recognizable and can easily be separated from the members of the Sylviidae family according to the existence of the septum nasi and the developmental level of the protuberantia caudolateralis.

\section{Sylviidae}

(Sylvia Scopoli, 1769; Acrocephalus J. A. et F. Naumann, 1811; Lusciniola Gray, 1841; Locustella Kaup, 1829; Hippolais Baldenstein, 1827; Phylloscopus Boie, 1826; Cisticola Kaup, 1829; Cettia Bonaparte, 1834)

The slightly curved upper beak is slim, aharp and the nostril is spacious. The septum nasi is always absent in the naval cavity. The brachium processi maxillopalatini is invisible through the nostirls in plan view and the spacious foramen basale is always located at its base. The structure of the corpus processi maxillopalatini and the vomer differ by genera. The incisura interpalatina is particularly wide in Sylvia species. In Cettia and Sylvia species, the lamella caudolateralis is rounded, but in the species of other genera, this bone plate is sword-like lengthened and sharp. The single (not split) foramen orbitonasale is usually spacious and little lengthened aperture. The septum interorbitale is strongly perforated, the fenestra olfactoria and the fenestra septi interorbitalis are equally spacious. The processus postorbitalis and the processus zygomaticus ossis squamosi are vestigial. The foramina venae occipitalis externae are a little far from each other and from the edge of the foramen magnum. The mandible is thin, lengthened, the impressio mandibularis is weakly expressed and the fenestra mandibulae is moderately spacious. The ventral surface of the pars caudalis mandibulae is smooth and the fossa caudalis mandibulae is barely notched.

Comment: This family contains osteo-morphologically little differentiated genera, thus the determination of species in practice is usually not feasible based on their cranial morphology. 
However, the whole Sylviidae family can be well separated from the similar Muscicapidae family based on the structure of the foramen orbitonasale, the position of the brachium processi maxillopalatini and the foramina venae occipitalis externae and the notched fossa caudalis mandibulae.

\section{Muscicapidae (s. 1.)}

(Muscicapa Brisson, 1760; Ficedula Brisson, 1760; Cercotrichas Boie, 1831; Saxicola Bechstein, 1803; Phoenicurus T. Forster, 1817; Oenanthe Vieillot, 1816; Monticola Boie, 1822; Luscinia T. Forster, 1817; Turdus Linnaeus, 1758; Erithacus Cuvier, 1800)

The upper beak is usually thin, lengthened, and in some genera (in the Muscicapinae subfamily), it is broadened at the base of the beak. The nostril is spacious and the lack of the septum nasi is typical in most of the genera. The brachium processi maxillopalatini is usually visible in plan view (through the nostrils) and the foramen basale opens at its base. The structure of the vomer is varied by genera and the processus corniculatus vomeris is usually vestigial. The foramen orbitonasale is split and the two apertures are sometimes located relatively far from each other. The fenestra olfactoria is flattened and the fenestra septi interorbitalis is a little more spacious. The processus postorbitalis and the processus zygomaticus ossis squamosi are both vestigial. The foramina venae occipitalis externae usually open close to each other at the end of the paired sulcus occipitalis. The mandible is slim, the impressio mandibularis is weakly expressed and the fenestra mandibulae is relatively narrow. The tuberculum pseudotemporale is relatively absent and the processus coronoideus is vestigial. The fossa caudalis mandibulae - opposite to the members of the Sylviidae family is deeply notched.

Comment: Some genera within this family are distinguishable from other members based on some certain osteological traits. The concavity on the ridge of the upper beak is typical for the Phoenicurus and Oenanthe genera. The foramen orbitonasale laterale is remarkably shifted outwards in Luscinia species and it is also visible in plan view. The strongly protuberant ala tympanica is typical for Turdus. Furthermore, the brachium processi maxillopalatini and the position of the foramina venae occipitalis externae can be modified in these species. Among the European members of this family, the well-developed septum nasi can only be found in the nasal cavity of Erithacus rubecula.

\section{Motacillidae}

(Motacilla Linnaeus, 1758; Anthus Bechstein, 1805)

The upper beak is slim and sharp, the nostril is spacious and the septum nasi is always absent. A weak concavity can be found on the dorsal beak of Anthus species before the nostril. The brachium processi maxillopalatini is visible through the nostril in plan view and the foramen basale is absent at its base. The incisura interpalatina is wide, rostrally strongly lengthened and the processus spiniformis is particularly long and slim in Motacilla species. The foramen orbitonasale is usually single (Motacilla spp., Anthus 
pratensis, A. spinoletta, A. cervinus), but in some Anthus species it is split (A. trivialis, A. campestris). The fenestra olfactoria and the fenestra septi interorbitalis are both spacious. The processus postorbitalis is vestigial, the larger processus zygomaticus ossis squamo$s i$ is sharply peaked. The foramina venae occipitalis externae open just behind the edge of the foramen magnum. The mandible is slim, the fenestra mandibulae is moderately spacious. The processus externus is short and angular, a weak bone ridge extends at the ventral surface of the processus internus.

\section{Prunellidae}

(Prunella Vieillot, 1816)

The upper beak is slim and sharp, a weak concavity can be found on its dorsal part. The nostril is spacious and the septum nasi is absent. The brachium processi maxillopalatini is invisible in plan view, the foramen basale is absent at its base. The lamella caudolateralis palatina is short and typically rounded. The foramen orbitonasale is a single (not split) aperture. The fenestra olfactoria and the fenestra septi interorbitalis are both spacious. The processus postorbitalis is vestigial, but the processus zygomaticus ossis squamosi is well-developed and its peak is widely rounded. The peak of the lamina basiparasphenoidalis is shortened. The mandible is slim, the fenestra mandibulae is moderately spacious. A weak bone ridge is located at the ventral surface of the pars caudalis mandibulae.

Comment: The developmental level of the processus zygomaticus ossis squamosi and the shape of the lamella caudolateralis palatina help in separating Prunella species from any other small, insectivorous songbirds.

\section{Passeridae}

(Passer Brisson, 1760; Petronia Kaup, 1829; Montifringilla C. L. Brehm, 1828)

The upper beak is relatively short and conical, the nostril is moderately spacious. The septum nasi is always located in the naval cavity. The split on the palate (fenestra palatina) wedges forward to approximately the half of the bony palate. The contour of the short and partially pneumatized corpus processi maxillopalatini is angular. The paired processus corniculatus vomeris at the peak of the vomer is particularly wide and dorsally hooked. The relatively wide incisura interpalatina is wedged toward the collum vomeris. The foramen orbitonasale is single (not split). The membrane which separates the eye sockets (septum interorbitale) is significantly bony and the fenestra septi interorbitalis is absent. The processus postorbitalis and the processus zygomaticus ossis squamosi are both well-developed and on the latter an extra lateral extension can be found. The foramina venae occipitalis externae are far from each other. The mandible is relatively short, the symphysis is moderately developed and the foramina postsymphysialia opens at the base of the mandible branches. The tuberculum pseudotemporale and the processus coronoideus are both well-developed. The foramen laterale opens at the beginning of the deep impressio mandibularis. The ventral surface of the pars caudalis mandibulae is smooth and its lateral edge is peaked. The 
peak of the processus externus mandibulae points to the symmetry axis of the mandible and the fossa caudalis is deeply notched.

Comment: The developmental level of the septum nasi is typical for the whole Passeridae family among all European conical beaked passerine birds. Some similar bone membrane can exceptionally be found in some species of the Fringillidae, but never in the European members of the Emberizidae families.

Fringillidae (s. str.)

(Fringilla Linnaeus, 1758; Serinus Koch, 1816; Chloris Cuvier, 1800; Carduelis Brisson, 1760; Acanthis Borkhausen, 1797; Carpodacus Kaup, 1829; Pinicola Vieillot, 1807; Pyrrhula Brisson, 1760; Loxia Linnaeus, 1758; Coccothraustes Brisson, 1760)

The upper conical beak and the mandible are remarkably shortened and the nostril is relatively small. The septum nasi in well-development state can only be found in C. coccothraustes and it is vestigial in Pinicola enucleator, while it is absent in most of the species. The bony palate is particularly developed, the fenestra palatina is shifted backwards. The corpus processi maxillopalatini is lengthened, the vomer is partially pneumatized. The incisura interpalatina is completely bony in the Carduelinae subfamily, but it is narrow and forms a lengthened gap in Fringilla species (Fringillinae subfamily). A well-developed bone ridge usually extends at the ventral surface of the lamella caudolateralis. The foramen orbitonasale is a single (not split) aperture. The septum interorbitale which separates the eye sockets, is robust, the fenestra septi interorbitalis can only be found in Fringilla species but this aperture is bony in the member of the Carduelinae subfamily. The fenestra olfactoria is also reduced in proportion to specialization. The processus postorbitalis is usually small but the processus zygomaticus ossis squamosi is highly developed in specialized species. The foramina venae occipitalis externae open at the edge of the foramen magnum. The thickening of the symphysis and the existence of the crista anterioventralis at the ventral surface of the pars caudalis mandibulae are typical for the mandible. The processus coronoideus is markedly peaked and behind it, the well-developed tuberculum pseudotemporale is also visible in lateral view. The foramen laterale open at the beginning of the deep impressio mandibularis.

Comment: The existence of the crista anterioventralis is only typical in the Fringillidae family which distinguishes all members of this family from any other songbirds.

\section{Emberizidae}

(Emberiza Linnaeus, 1758; Calcarius Bechstein, 1803; Plectrophenax Stejneger, 1882)

The upper beak is thinner and slimmer than in the Passeridae and Fringillidae families and the contour line has a typical fracture at the midpoint in lateral view. The nostril is relatively spacious, the processus postnarialis is thin and the septum nasi is always absent in the naval cavity. The corpus processi maxillopalatini is lengthened and partially pneumatized. 
The developed lateral extension of the twin peaked processus corniculatus vomeris is slim. The wide incisura interpalatina is rostrally lengthened towards the collum vomeris. The pars interorbitalis is markedly narrow. Differently to the seed-eater songbirds, the septum interorbitale which separates the eye sockets is strongly perforated. The fenestra septi interorbitalis is more spacious in Emberiza species than the fenestra olfactoria; in the Calcarius and the Plectrophenax this aperture is smaller or could be exceptionally bony. The processus postorbitalis is vestigial, however the processus zygomaticus ossis squamosi is wide and forms a rounded bone plate. The ala tympanica is some species (Emberiza cia, E. citrinella) is particularly developed. The angulus mandibulae is typically peaked and the curve of the mandible is refracted near the deep impressio mandibularis in lateral view. The symphysis is moderately thick and the foramina postsymphysialia are visible at the base of the mandible branches in bottom view. The fenestra mandibulae is spacious, the processus coronoideus and the tuberculum pseudotemporale are both well-developed. The ventral surface of the pars caudalis mandibulae is smooth and the fossa caudalis mandibulae is deeply notched.

Comment: The members of the Emberizidae family can easily be distinguished from the members of other bird families based on the refracted curve of the mandible.

\section{Alaudidae \\ (Galerida Boie,1828; Calandrella Kaup, 1829; Melanocorypha Boie, 1828; Eremophila Boie, 1828; Lullula Kaup, 1829; Alauda Linnaeus, 1758)}

The peak of the beak is relatively blunt, a lengthwise groove extends on the midline of the bony palate. A tiny aperture is located next to the rostral connection point of the lamella craniolateralis (this is absent in species of other families). The bone membrane (septum nasi) between the spaciour nostrils is vestigial but it can be found in all species. The foramen basale and the brachium processi maxillopalatini are both visible through the nostrils in plan view. The corpus processi maxillopalatini is lengthened and pneumatized. Particularly well-developed, paired processus corniculatus vomeris is located at the beginning of the relatively short vomer. The exceptionally wide incisura interpalatina is singnificantly lengthened to the front of the processus spiniformis. The pars interorbitalis is narrow. The septum interorbitale is robust and the foramen septi interorbitalis becomes completely bony by the age of the indicidual (usually at very young). The fenestra olfactoria can be found in every species. The single (not split) foramen orbitonasale opens close to the axis of the skull in the eye cavity. The processus orbitosphenoidalis lateralis is well-developed in some members of the family (Eremophila, Melanocorypha, Calandrella) but it is absent in others. The well-developed processus postorbitalis and the processus zygomaticus ossis squamosi are melted into a single extension on their peaked ends and a spacious aperture (fenestra postorbitalis) is located between the bases of the two extensions. The rostrum sphenoidale is remarkably thicker in comparison to the insectivorous passerine birds. The foramina venae occipitalis externae is located close next to the edge of the foramen magnum. The symphysis mandibulae is relatively short and a weak concavity can be found on 
its dorsal surface. The foramen postsymphysiale which opens at the symmetry axis is typical at the caudal edge of the symphysis. The mandible is slim in most of the members of this family, however the mandible of the specialized Melanocorypha species is robust. The fenestra mandibulae is moderately spacious and the short processus coronoideus forms a sharp bone ridge above it. The processus internus mandibulae is also visible in lateral view and its peak bends in dorsorostrally.

Comment: The fusion of the peak of the processus postorbitalis and the processus zygomaticus ossis squamosi which typical for the larks is absent in any other European songbird families. These two extension could be ended very close to each other in some woodpecker species (Piciformes: Picidae), but this analogous trait similar to larks can only be found among the members of Tetraonidae, Phasianidae (Galliformes) and Pteroclidae (Columbiformes) of the European avifauna.

Many characteristics of the upper beak, the position of the foramen postsymphysiale and the shape of the processus internus may be helpful in the determination of the larks in practice.

\section{Acknowledgements}

My research in the Hungarian National History Museum was highly supported by Dénes Jánossy, and I also thank the important contribution of Tibor Csörgő and Gábor Csorba. My work was helped by J. N. Kurochkin and A. Karhu from the Paleontological Institute in Moscow and E. Bauerfeind from the collection of the Naturhistorisches Museum in Vienna. I received materials from Tibor Farkas, from South Africa for the comparison of cranial morphology of shrikes. The Hungarian script was translated by Jenö Nagy and the text was supervised by Tibor Pecsics and Béla Solti. I am grateful for all of their help. 


\section{References}

Bacher, A. 1967. Vergleichend morphologische Untersuchungen an Einzelknochen des postcranialen Skeletts in Mitteleuropa vorkommender Schwäne und Gänse [Comparative morphological examinations of the individual bones of postcranial skeletons of swans and geese in Central Europe]. - Inaug.- Diss. Tierärtztl. Univ., München (in German)

Baumel, J. J., King, A. S., Lucas, A. M., Breazile, J. E. \& Evans, H. E. 1979. Nomina anatomica avium. An annotated anatomical dictionary of birds. - Academical Press, London

Barbosa, A. 1991. European waders identification key on the basis of the cranial morphology. - Ardeola 38(2): 249-263.

Boas, J. E. V. 1929. Biologisch-anatomische Studien über den Hals der Vögel. - Det Kongelige Danske Videnskabernes Selskabs Skrifter. Naturvidenskabelig og Mathematisk Afdeling (in German)

Bochenski, Z. M. 1994. The comparative osteology of grebes (Aves: Podicipediformes) and its systematic implications. - Acta Zoologica Cracoviensia 37(1): 191-346.

Boev, Z. N. 1988. Osteological features for identification of herons (Aves, Ardeidae). - Acta Zoologica Bulgarica 36: 56-62.

Cuisin, J. 1989. L'identification des crânes de passereaux (Passeriformes: Aves) [The identification of the skulls of passeriform birds]. - Doct. dissertation, Universite de Bourgogne (in French)

Ebersdobler, K. 1968. Vergleichend morphologische Untersuchungen an Einzelknochen des postcranialen Skeletts in Mitteleuropa vorkommender mittelgrosser Hühnervögel [Comparative morphological examinations of the individual bones of postcranial skeletons of medium sized galliform birds]. - Inaug.- Diss. Tierärtztl. Univ., München (in German)

Fick, O. K. W. 1974. Vergleichend morphologische Untersuchungen an Einzelknochen europäischer Taubenarten [Comparative morphological examinations of the individual bones of European pigeons and doves]. - Inaug.Diss. Tierärtztl. Univ., München (in German)

Finckenstein, H. von 1937. Die Artbestimmung der häufigsten deutschen Fringillidae nach dem Schädelskelett [The identification of the common german finch species after their skull bones]. - Anzeiger der Ornithologischen Gesellschaft, Bayern 2: 393-403. (in German)

Fürbringer, M. 1888. Untersuchungen zur Morphologie und Systematik der Vögel: zugl. e. Beitr. zur Anatomie d. Stütz- u. Bewegungsorgane, Vol. 1. [Morphological examinations and taxonomy of birds. The role of antomy in the locomotor system. Vol 1.]. - Van Holkema

Hinchliffe, J. R. 1985. One, two, three'or 'two, three, four': an embryologist's view of the homologies of the digits and carpus of modern birds. - The beginnings of birds. Willibaldsburg, Germany: Freunde des Jura-Museumd Eichstätt, pp. 141-147.

Hofer, H. 1945. Untersuchungen über den Bau des Vogelschädels, besonders über den der Spechte und Steißhühner [Examinations of the architecture of the bird skulls especially on woodpeckers and tinamous]. - Zoologische Jahrbuch (Anatomie und Ontogenie der Tiere) 69: 1-158. (in German)

Huxley, T. H. 1867. On the classification of birds: and on the taxonomic value of the modifications of certain of the cranial bones observable in that class. - Proceedings of the Zoological Society of London 1867: 415-472.

Jánossy, D. 1983. Humeri of Central Europaean smaller Passeriformes. - Fragmenta Mineralogica et Palaeontologica 11: 85-112.

Jánossy, D. 1992. Lower Pleistocene bird remains from Beremend (S-Hungary, Loc. 15. and 16.). - Aquila 99: 9-25.

Kessler, J. 2015. Osteological guide of songbirds from Central Europe. - Ornis Hungarica 23(2): 62-155. DOI: 10.1515/orhu-2015-0016

Kessler, J. 2016. Picidae in the European fossil, subfossil and recent bird faunas and their osteological characteristics. - Ornis Hungarica 24(1): 96-114. DOI: 10.1515/orhu-2016-0006

Kraft, E. 1972.Vergleichend morphologische Untersuchungen an Einzelknochen nord- und mitteleuropäischer kleinerer Hühnervögel [Comparative morphological examinations of the individual bones of postcranial skeletons of small sized galliform birds]. - Inaug.-Diss. Tierärtztl. Univ., München (in German)

Lambrecht, K. 1933. Handbuch der Paläornithologie [Handbook of Palaornithologie]. - Borntraeger, Berlin (in German)

Langer, G. 1980. Vergleichend morphologise Untersuchungen an Einzelknochen in Mitteleuropa vorkommender mittelgrosser Eulenarten [Comparative morphological examinations of the individual bones of postcranial skeletons of medium sized owl species in Central Europe]. - Inaug.-Diss. Tierärtztl. Univ., München (in German) 
März, R. 1987. Gewöll- und Rupfungskunde [Handbook of bird pellets and droppings]. - Akademie-Verlag, Berlin (in German)

Moreno, E. 1985, 1986, 1987. Clave osteologica para la identification de los Passeriformes Ibericos, I., II., III. [Osteological identification key of lberian Passerformes. I., II., III.]. - Ardeola 32(2): 295-377; 33(1-2): 69$129 ; 34(2): 243-273$.

Otto, Ch. 1981. Vergleichend morphologische Untersuchungen an Einzelknochen in Zentraleuropa vorkommender mittelgrosser Accipitridae. I.: Schädel, Brustbein, Schultergürtel und Vorderextremität [Comparative morphological examinations of the individual bones of postcranial skeletons of medium sized Accipitridae in Central Europe I.: Skull, Breastbone, Shoulder girdle, Forelimbs (Wings)]. - Inaug.-Diss. Tierärtztl. Univ., München (in German)

Schmidt-Burger, P. 1982. Vergleichend morphologische Untersuchungen an Einzelknochen in Zentraleuropa vorkommender mittelgrosser Accipitridae II. [Comparative morphological examinations of the individual bones of postcranial skeletons of medium sized Accipitridae in Central Europe II]. - Inaugural-Dissertation Tierärtztlixhe Universitat, München (in German)

Sibley, C. G. \& Ahlquist, J. E. 1990. Phylogeny and classification of birds. - Yale University Press, New Haven, Conn., USA

Solti, B. 1980. Beiträge zur Kenntnis der Osteologie des Gerfalken (Falco rusticolus L., 1758) [The osteology of the Gyrfalcon (Falco rusticolus L., 1758)]. - Folia Historico-naturalia Musei Matraensis 6: 189-204.

Solti, B. 1981a Osteologische Untersuchungen an Falco biarmicus Temminck, 1825. [The osteology of the Lanner Falcon (Falco biarmicus)]. - Folia Historico-naturalia Musei Matraensis 7: 135-151.

Solti, B. 1981b Vergleichend-osteologische Untersuchungen am Skelettsystem der Falkenarten Falco cherrug Gray und Falco peregrinus Tunstall [Comparative examinations of the skeletal systems of Falco cherrug Gray und Falco peregrinus Tunstall]. - Vertebrata Hungarica 20: 75-125. (in German with English Summary)

Solti, B. 1994. The comparative osteomorphological study of the european small-statured falcons (Aves: Falconidae). - Folia Historico-naturalia Musei Matraensis 21: 1-282.

Steiner, H. 1922. Die ontogenetische und phylogenetische Entwicklung des Vogelflügelskelettes [The ontogenetic development and phylogenetic evolution of the bird skeleton]. - Acta Zoologica 3(2-3): 307-360. (in German)

Suschkin, P. 1905. Zur morphologie des Vogelskelets. Vergleichende Osteologie der normalen Tagraubvögel (Accipitres) und die Fragen der Classification [The morphology of the bird skeleton. Comparative osteology of raptors (Accipitres) and taxonomic questions]. - Moscow, pp. 1-247. (in German)

Tomek, T. \& Bochenski, Z. M. 2000. The comparative osteology of European corvids (Aves: Corvidae), with a key to the identification of their skeletal elements. - Publications of the Institute of Systematics and Evolution of Animals, Kraków

Ujhelyi, P. 1992. Identification of the Fringillidae of Europe on the basis of craniometric characteristics. - Aquila 99: 99-110.

Voous, K. H. 1977. List of recent Holarctic bird species, Passerines. - Ibis 119: 223-250, 376-406.

Winde, H. 1970. Osteologische Untersuchungen an einigen deutschen Eulenarten (Strigidae) [Osteological examination of some german owl species]. - Zoologische Abhandlugen des Staatlichen Museums für Tierkunde in Dresden 30: 149-157. (in German)

Witmer, L. M. \& Martin, L. D. 1987. The primitive features of the avian palate, with special reference to Mesozoic birds. - Documents des Laboratoires de Geologie de la Faculte des Sciences de Lyon 99: 21-40.

Woelfle, E. 1967. Vergleichend morphologische Untersuchungen an Einzelknochen des postcranialen Skeletts in Mitteleuropa vorkommender Enten, Halbgänse und Säger. [Comparative morphological examinations of the individual bones of postcranial skeletons of ducks, shelducks-sheldgeese and sawbills in Central Europe]. Inaug.-Diss. Tierärtztl. Univ., München (in German)

Yudin, K. А. 1978. Классические морфологические признаки и современная систематика птиц [The classical morphological features and the modern avian classification]. - Proceedings of the Zoological Institute Academy of Sciences USSR, 76: 3-8. (in Russian)

Zusi, R. L. 1993. Patterns of diversity in the avian skull. - The Skull 2: 391-437.

Zweers, G. A., Vanden Berge, J. C. \& Koppendraier, R. 1987. Avian cranio-cervical systems. Part I: Anatomy of the cervical column in the chicken (Gallus gallus L.). - Acta Morphologica Neerlando-Scandinavica 25(3): $131-155$. 

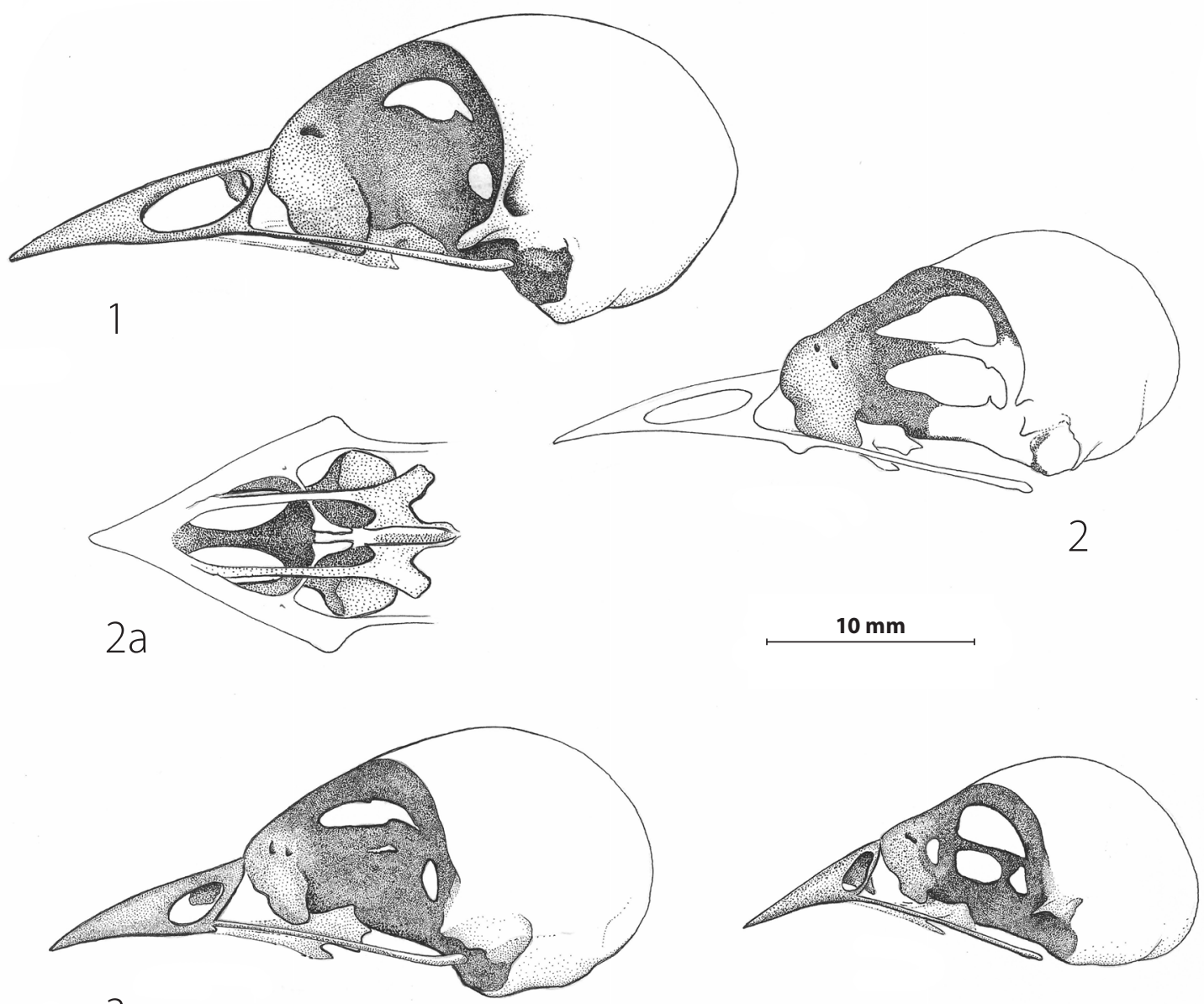

3

4
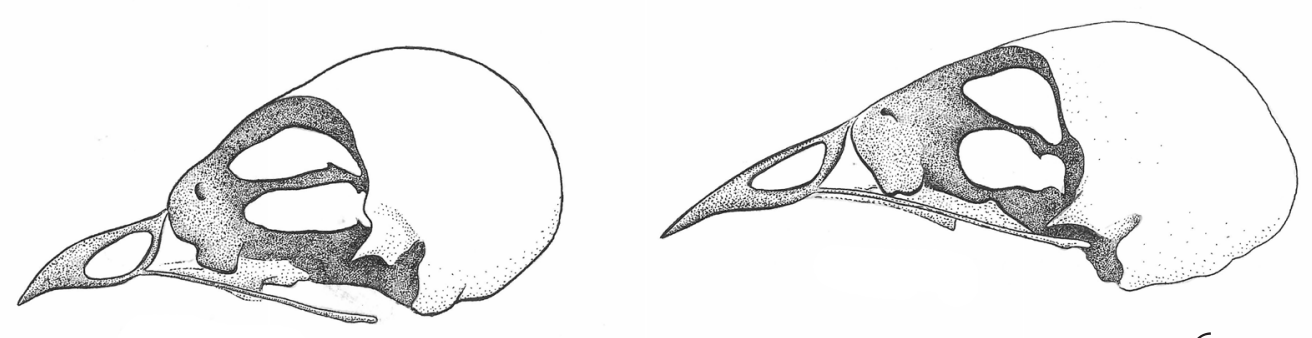

5

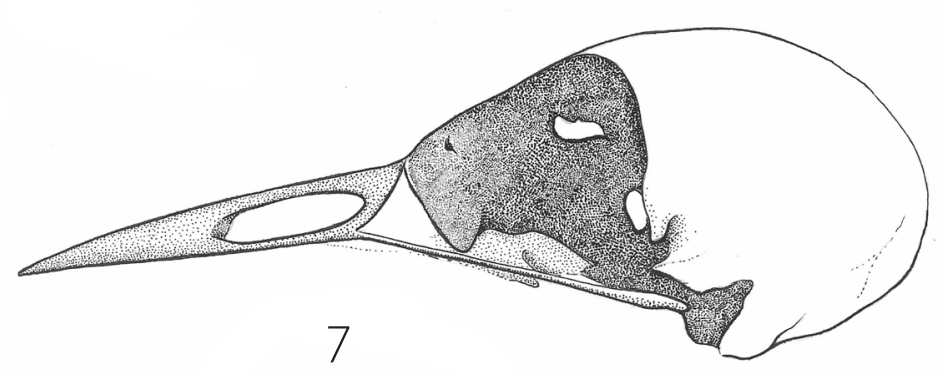

6

Plate 1. Skulls

1. táblakép Koponyák

1. Alauda, 2. Hirundo, 3. Parus, 4. Remiz, 5. Aegithalos, 6. Panurus, 7. Sitta 

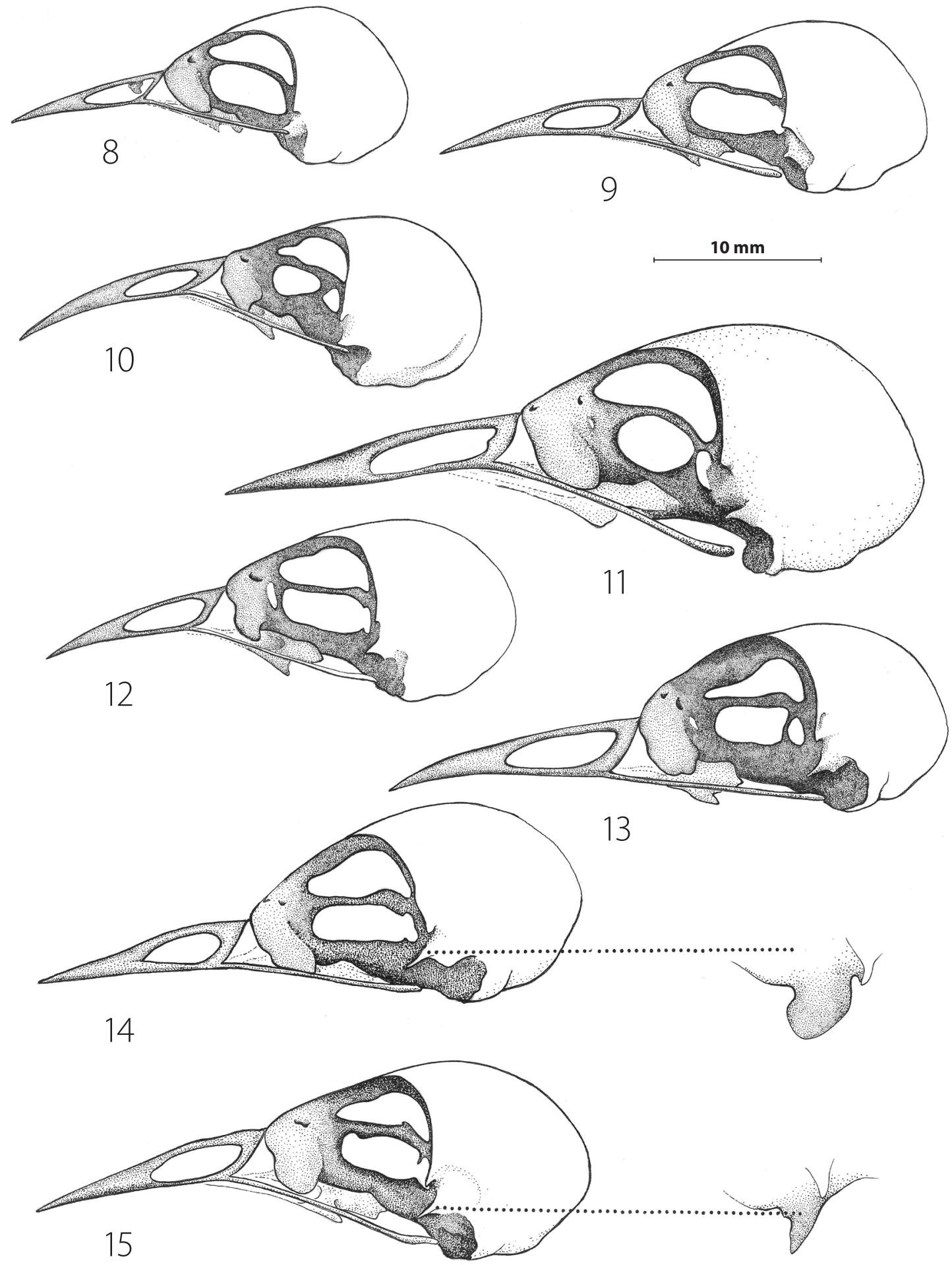

Plate 2. Skulls

2. táblakép Koponyák

8. Regulus, 9. Troglodytes, 10. Certhia, 11. Cinclus, 12. Sylvia, 13. Muscicapa, 14. Prunella, 15. Motacilla 


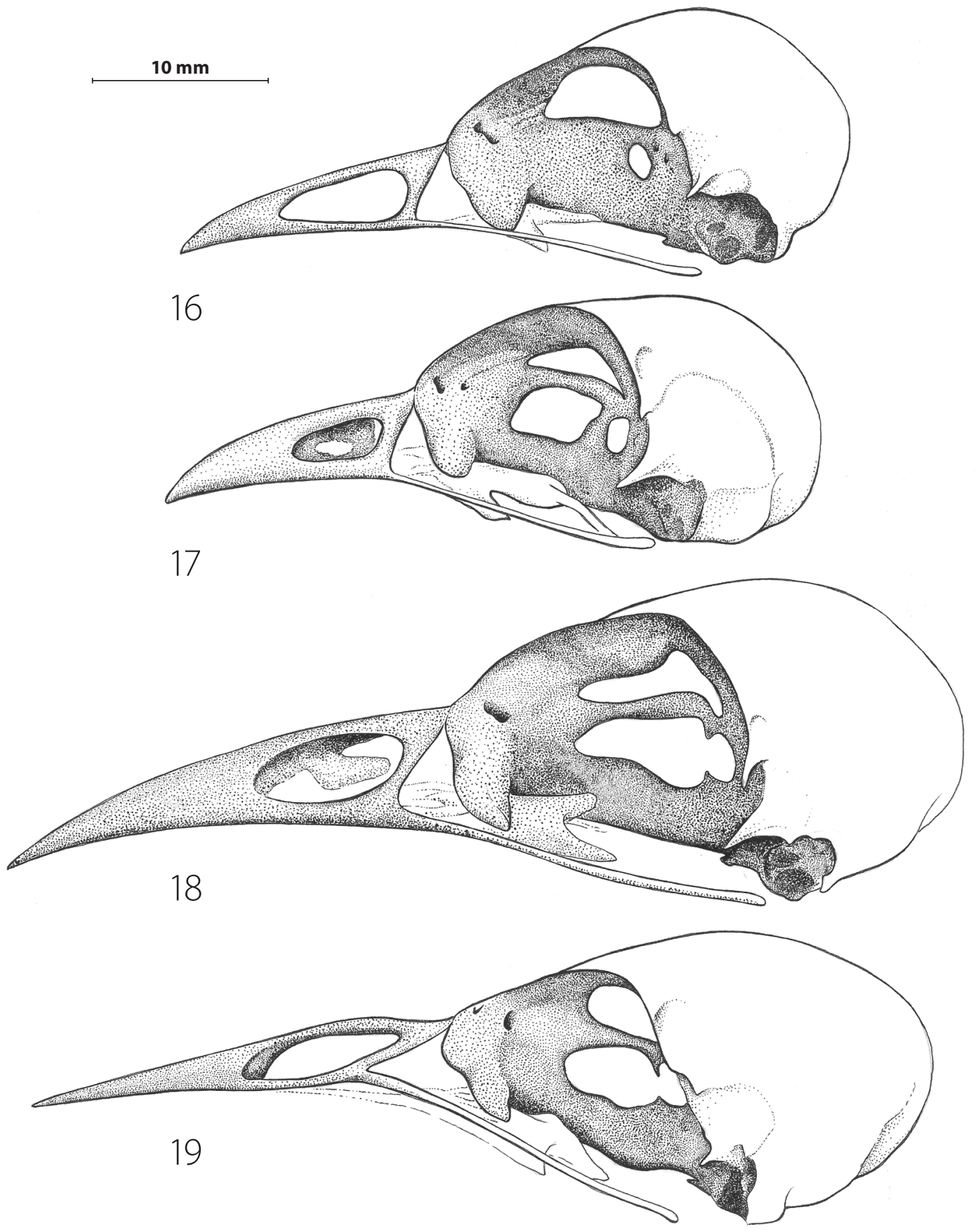

Plate 3. Skulls

3. táblakép Koponyák

16. Bombycilla, 17. Lanius, 18. Oriolus, 19. Sturnus 

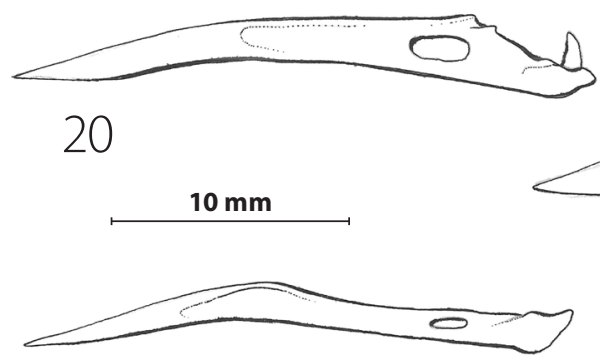

22
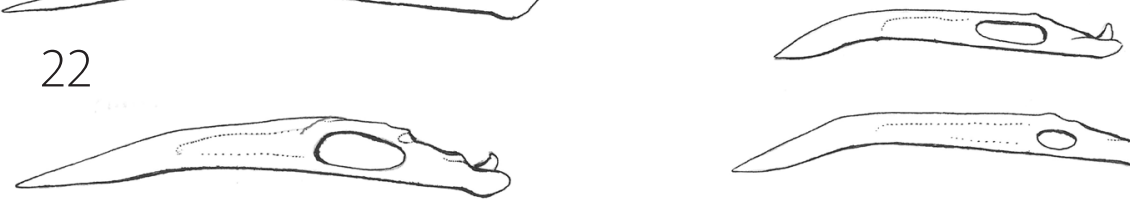

21

23
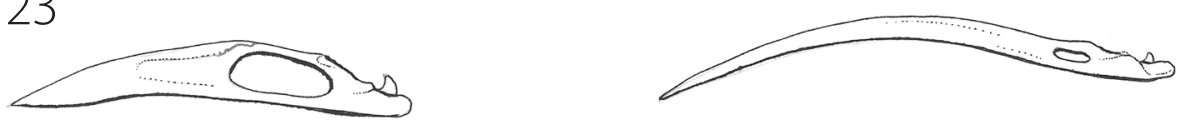

24
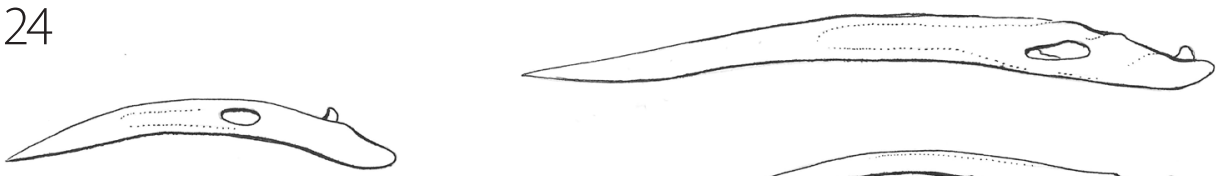

25
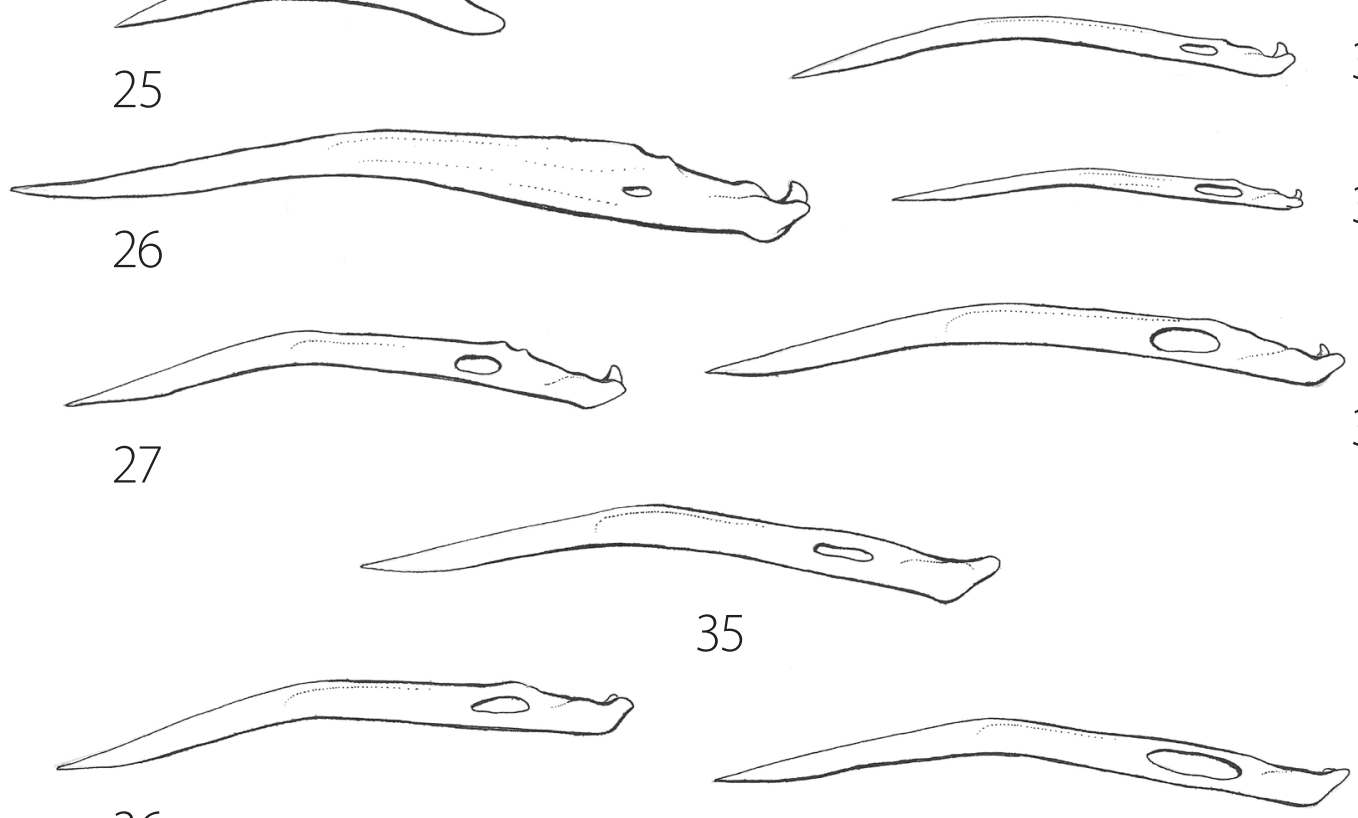

36

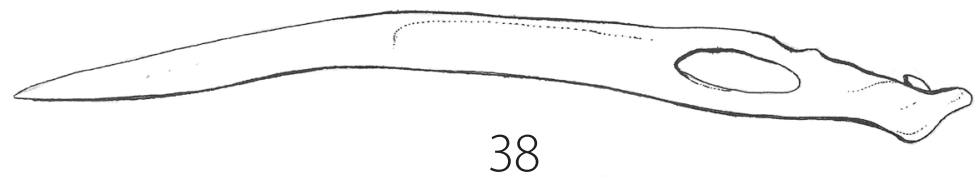

Plate 4. Lower jaws

4. táblakép Állkapcsok

20. Galerida, 21. Melanocorypha, 22. Hirundo, 23. Parus major, 24. P. caeruleus, 25. Remiz, 26. Cinclus,

27. Prunella, 28. Aegithalos, 29. Panurus, 30. Certhia, 31. Sitta, 32. Troglodytes, 33. Regulus, 34. Motacilla,

35. Muscicapa, 36. Sylvia, 37. Luscinia, 38. Turdus 


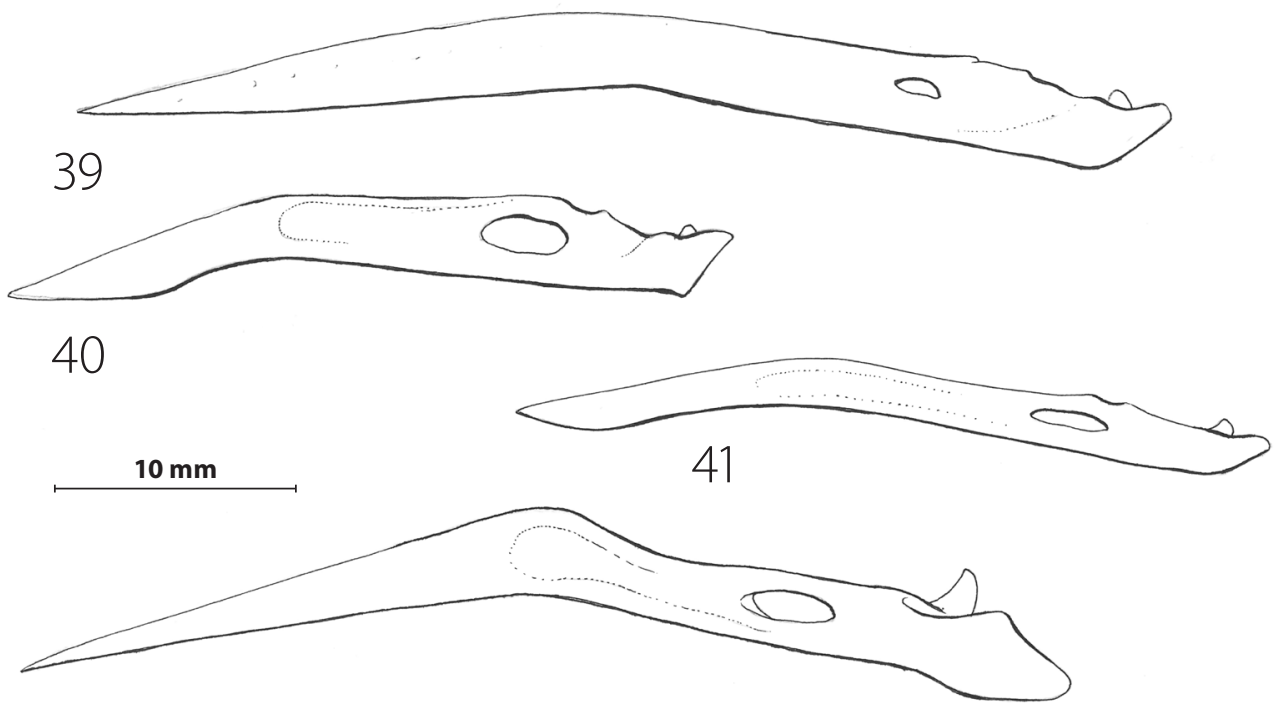

42
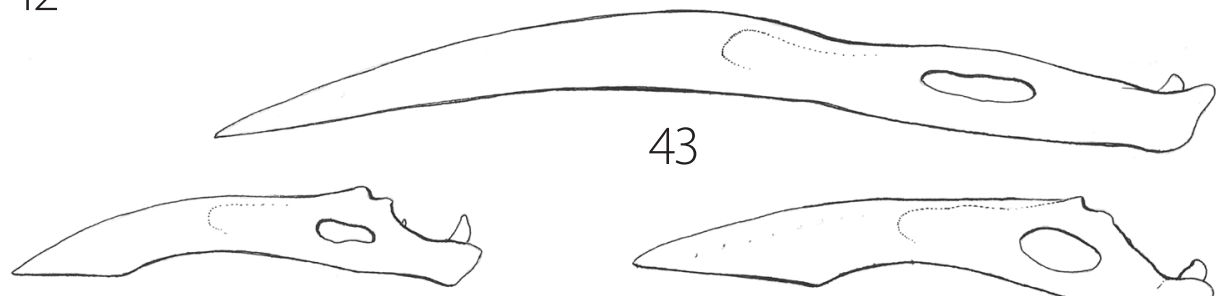

44
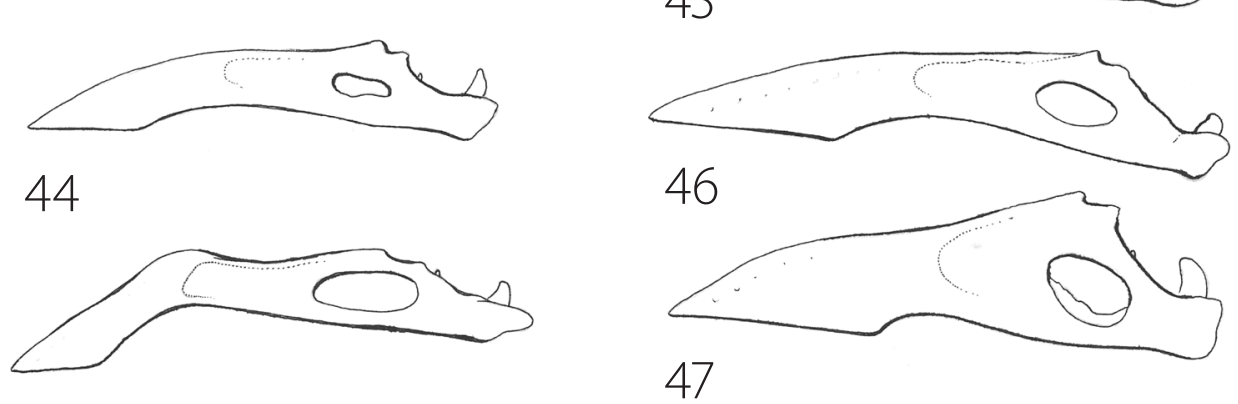

45 

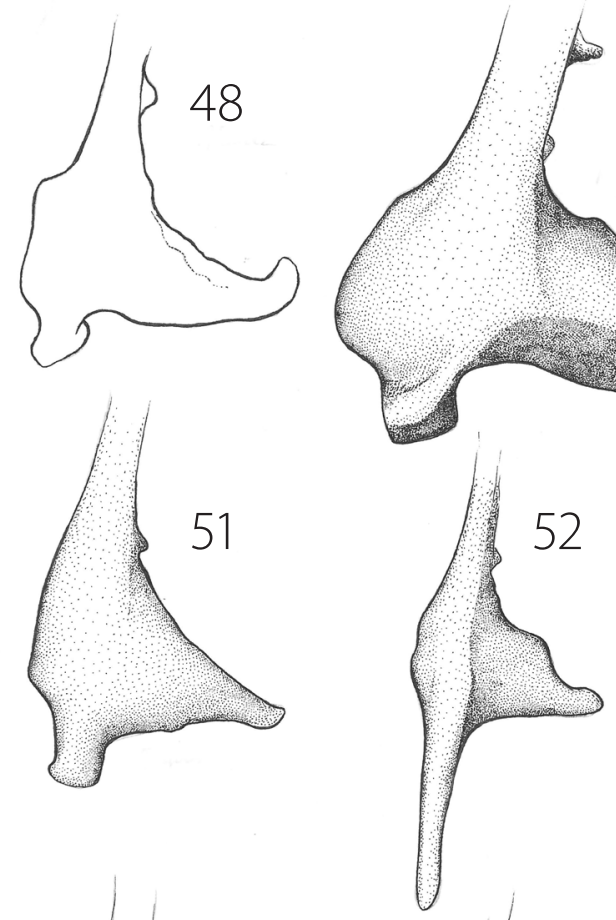

49
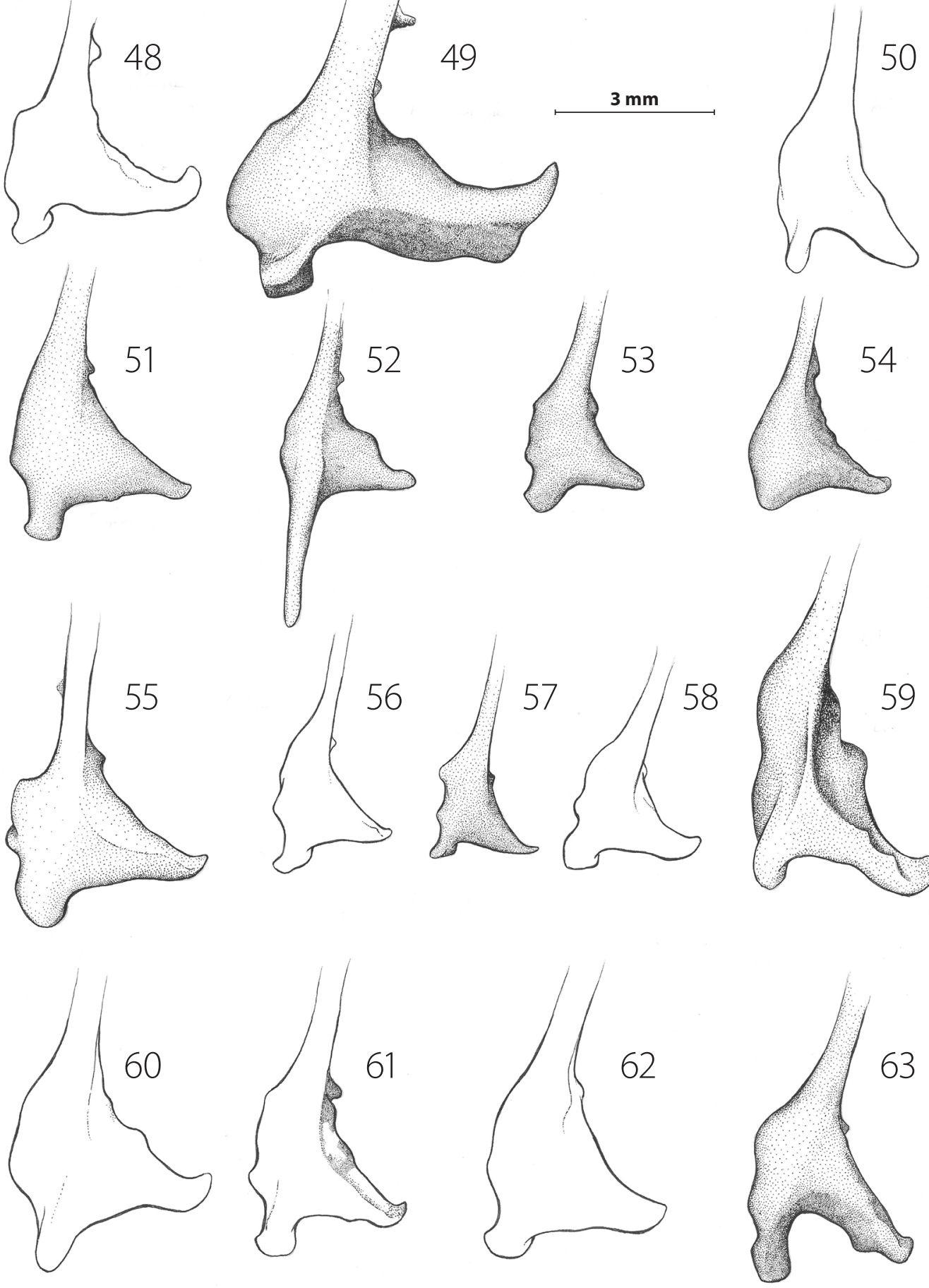

Plate 6. Caudal part of the lower jaws

6. táblakép Az állkapocs caudalis része

48. Alauda, 49. Melanocorypha, 50. Hirundo, 51. Parus, 52. Remiz, 53. Aegithalos, 54. Panurus, 55. Sitta,

56. Certhia, 57. Regulus, 58. Troglodytes, 59. Cinclus, 60. Prunella, 61. Motacilla, 62. Sylvia, 63. Muscicapa 


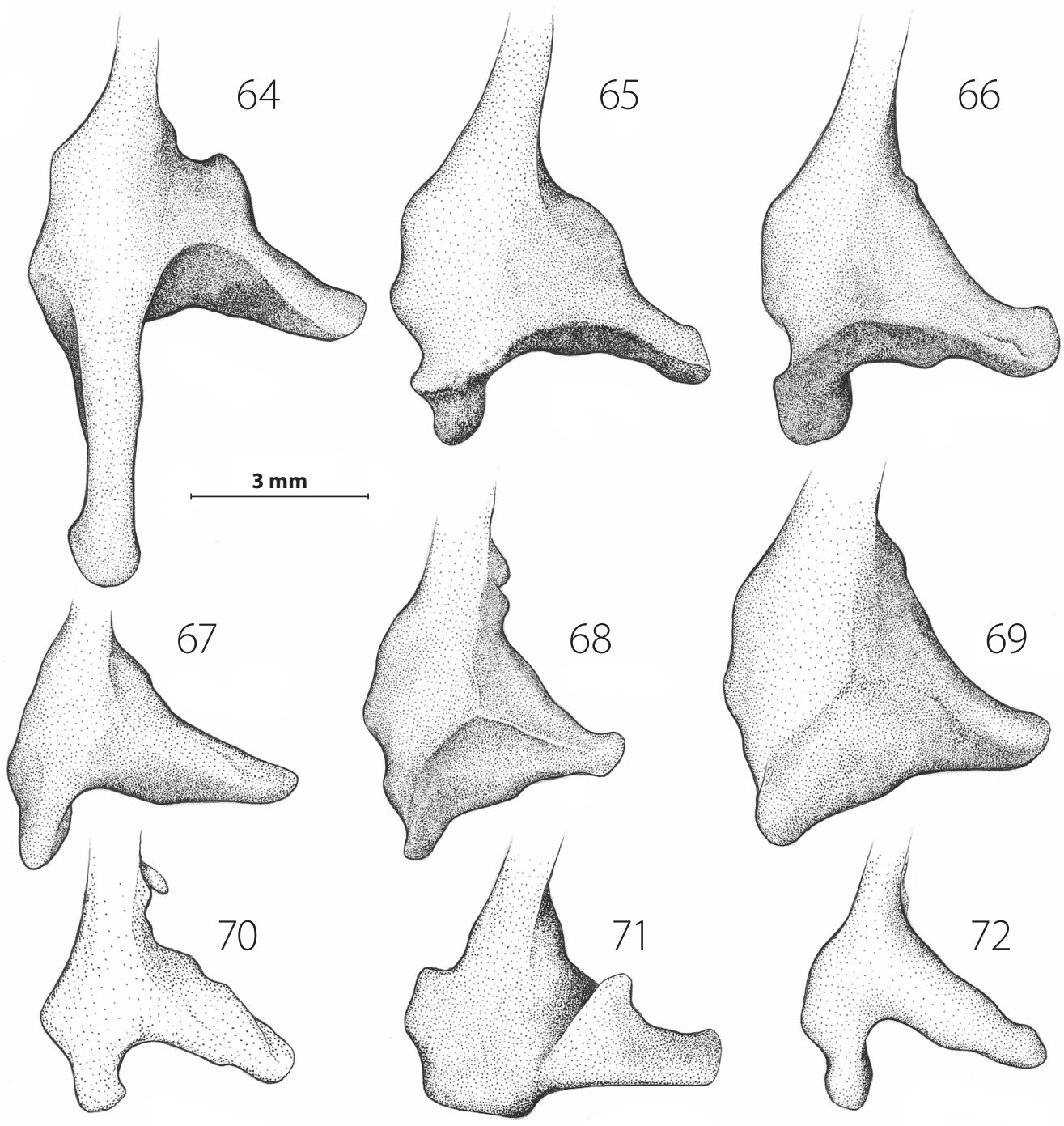

Plate 7. Caudal part of the lower jaws

7. táblakép Az állkapocs caudalis része

64. Sturnus, 65. Pastor, 66. Turdus, 67. Bombycilla, 68. Lanius, 69. Oriolus, 70. Passer, 71. Chloris, 72. Emberiza 